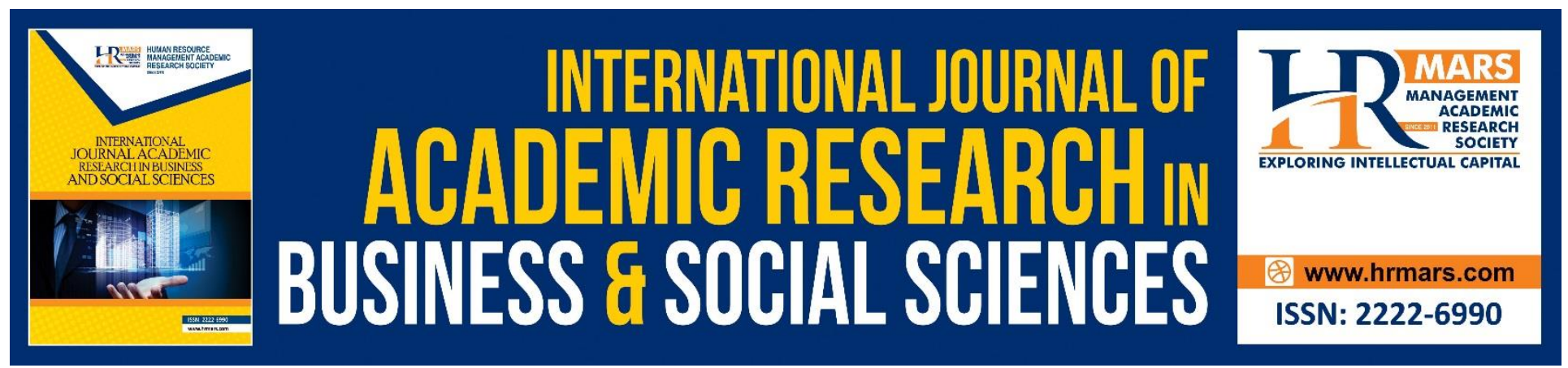

\title{
Governance, Location, Size and Waqf Efficiency in Malaysia
}

\section{Dahlia Ibrahim, Haslindar Ibrahim}

To Link this Article: http://dx.doi.org/10.6007/IJARBSS/v10-i10/7651

DOI:10.6007/IJARBSS/v10-i10/7651

Received: 08 August 2020, Revised: 30 August 2020, Accepted: 14 September 2020

Published Online: 27 October 2020

In-Text Citation: (Ibrahim, \& Ibrahim, 2020)

To Cite this Article: Ibrahim, D., \& Ibrahim, H. (2020). Governance, Location, Size and Waqf Efficiency in Malaysia. International Journal of Academic Research in Business and Social Sciences. 10(10), 589-612.

Copyright: (c) 2020 The Author(s)

Published by Human Resource Management Academic Research Society (www.hrmars.com)

This article is published under the Creative Commons Attribution (CC BY 4.0) license. Anyone may reproduce, distribute, translate and create derivative works of this article (for both commercial and non-commercial purposes), subject to full attribution to the original publication and authors. The full terms of this license may be seen

at: http://creativecommons.org/licences/by/4.0/legalcode

Vol. 10, No. 10, 2020, Pg. 589 - 612

http://hrmars.com/index.php/pages/detail/IJARBSS

JOURNAL HOMEPAGE

Full Terms \& Conditions of access and use can be found at http://hrmars.com/index.php/pages/detail/publication-ethics 


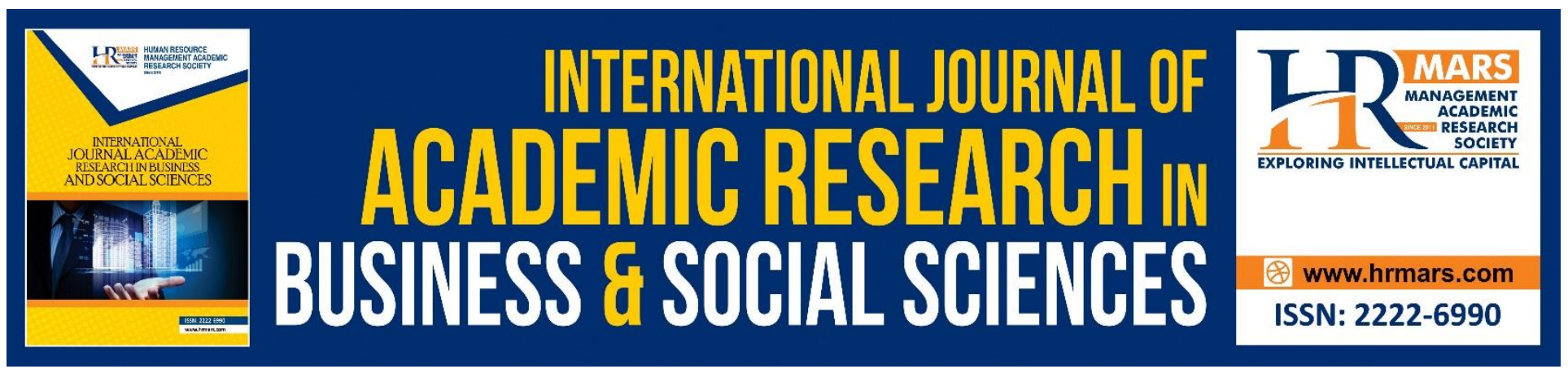

\title{
Governance, Location, Size and Waqf Efficiency in Malaysia
}

\author{
Dahlia Ibrahim \\ UiTM Merbok, Malaysia \\ Email: dahlia400@uitm.edu.my \\ Haslindar Ibrahim \\ School of Management, Universiti Sains Malaysia (USM), Malaysia \\ Email: haslindar@usm.my
}

\section{Abstract}

This study examines the relationship between corporate governance mechanisms, location, and size of organization with the efficiency of thirteen State Islamic Religious Councils (SIRCs) in managing waqf in Malaysia for the period 2007 to 2013. The measurement of the technical efficiency of the SIRCs uses two basic models of Data Envelopment Analysis (DEA). For the purpose of measuring the efficiency, this study uses three inputs and two outputs selected based on the intermediation approach. Based on efficiency scores, further investigation is made into the factors that are influential to the efficiency level of the SIRCs by evaluating the relationship between location, size of organization and governance mechanisms as measured by board size, board independence and board meeting against efficiency by using the panel data analysis. The findings show only one SIRC is fully efficient and the other twelve SIRCs are inefficient when analysis is done on a full sample of the thirteen SIRCs. Further analysis on the technical efficiency components also reveals that the SIRCs inefficiency mostly caused by managerial inefficiency, not scale inefficiency. Finally, the findings reveal that there is a significant relationship between all efficiency scores with location and the board size signifying that the SIRC Penang almost achieve full efficiency in their management of the waqf. Meanwhile, size of organization and board independence are significant with scale efficiency and pure technical efficiency respectively showing that large size organization are more efficient in their production process and the more outsiders in the board of directors, the less efficient is the SIRCs. Keywords: SIRCs, Technical Efficiency, Pure Technical Efficiency, Scale Efficiency.

\section{Introduction}

At the global front, the performance measurement has become an important agenda in many notfor-profit organization or public sectors regardless of field and size (Macpherson, 2001). One of the performance measures is the assessment of organization's efficiency. Witte and Geys (2011) stipulated that efficiency is widely applied in measuring performance of various sectors. Efficiency 
INTERNATIONAL JOURNAL OF ACADEMIC RESEARCH IN BUSINESS AND SOCIAL SCIENCES Vol. 10, No. 10, 2020, E-ISSN: 2222-6990 @ 2020 HRMARS

refers to the measurement and comparison of the ratio of the input and output combination. It indicates how well the combination of the input and output (as resources) transformed into products through a production process. In economic sense, efficiency looks at the relationship between the inputs and outputs in a production process and measures their performance against the production frontier (Coelli, Rao, Donnell \& Battese, 2005). As such, it is essential to look into the performance of an institution through the evaluation of its efficiency to unveil its degree of performance. By doing so, the management can make improvement to the production process.

At present, these issues are still encountered by many waqf institutions in the Muslim countries worldwide. In practice, the management of waqf is not an easy task to carry out. Its management subjects to embezzlement by whoever entrusted to manage them. Many Muslim countries encounter mismanagement of the waqf (Ihsan \& Hameed, 2011). Similarly, Malaysia is no exception to this scenario. Waqf issues in Malaysia started when the former Prime Minister of Malaysia, Abdullah Badawi found that waqf in Malaysia is underdeveloped and not properly managed which prompted him to establish the Department of Wakaf, Zakat and Haj (Wakaf, Haji-JAWHAR) in 2004 (Salleh and Muhammad, 2008). Ismail, Salim and Hanafiah (2015) emphasized that the enormity of waqf land in Malaysia can yield billions of incomes to the Muslim if these lands are managed and developed efficiently. Unfortunately, the enormous amount of the waqf does not help in generating income for these institutions because most of the waqf were not fully managed and developed by the SIRCs. On this matter, Alhabshi (1991) indicated that only 10 percent of the waqf are developed while the rest are not productive. Although the issue of the unproductive waqf was mentioned more than two decades ago, JAWHAR's officer ${ }^{1}$ mentioned that a lot of existing waqf under the SIRCs are still unproductive and not fully developed. As of 2011, the estimated total of the waqf land in Malaysia is at 11,094 hectares as exhibited by Jabatan Wakaf, Zakat dan Haji.

Sulaiman, Adnan and Nor (2009) found that it is important to look at the efficiency ratio to evaluate the performance of the waqf institutions by assessing the relationship between the inputs and outputs of the institutions. In a like manner, Hasim (2007) suggested that the waqf institutions apply an innovative step in encouraging an efficient collection of the waqf fund through insurance companies. Another study by Chowdhury, Chowdhury, Muhammad and Yasoa (2012) delved into the problems of waqf administration which include the lack of proficient staff, delay in the management process and lack of revenues to cover for its operation. They found that these problems expose waqf institutions to corruption and mismanagement that lead to delay in distributing the benefits of the waqf to the beneficiaries. Later, Hassan and Ahmad (2014) studied the relative efficiency of the waqf institutions in collecting and distributing waqf to the beneficiaries. On the legal aspect, Mahamood (2006) wrote about the different enactments as applied by the waqf institutions in Malaysia, specifically the State Islamic Religious Council.

As of present, the issues concerning the waqf have become a popular topic among many scholars. Many studies investigate the struggle to improve the waqf institutions. However, most of the studies are conceptual in nature and the empirical study of the waqf institutions' performance is highly limited. Therefore, the objectives of this study are:

\footnotetext{
${ }^{1}$ An interview conducted with Hj Zainal bin Haji Mohd Yusoh A.M.N of the JAWHAR on $13^{\text {th }}$ April 2013.
} 
INTERNATIONAL JOURNAL OF ACADEMIC RESEARCH IN BUSINESS AND SOCIAL SCIENCES Vol. 10, No. 10, 2020, E-ISSN: 2222-6990 @ 2020 HRMARS

- To examine the waqf institutions' efficiency among SIRCs in Malaysia.

- To know how efficient the waqf institutions utilize their resources in generating an optimum output of their operation.

- To investigate the corporate governance mechanisms as determinants in influencing the waqf efficiency among SIRCs in Malaysia.

\section{Literature Review}

\section{The SIRCs and Waqf Management in Malaysia}

As one of the established Muslim countries, Malaysia is not invisible to the issues in managing the waqf. The regulations governing the administration and management of the waqf in Malaysia maybe different from the other Muslim countries such as Singapore and Indonesia, but one aspect these countries have in common is their continuous effort in reforming their waqf administrations. Some measures have been taken by appointing the State Islamic Religious Councils (SIRCS) and other organizations such as Department of Waqaf, Zakat and Haj (Jabatan Wakaf, Zakat dan Haji-JAWHAR) to manage the waqf. Furthermore, government has taken an initiative steps by establishing Malaysian Waqf Foundation (Yayasan Wakaf Malaysia-YWM) in 2008. With the establishment of YWM, Department of Waqaf, Zakat and Haj (Jabatan Wakaf, Zakat dan Haji (JAWHAR) will be able to develop the waqf aggressively. In 2009, JAWHAR applied RM1,896.75 million from the Malaysian government under the Tenth Malaysian Plan. With the fund, an amount of RM1,826.75 million is used for sixty eight physical projects and RM70 million is used for four non-physical projects (Ahmad \& Muhamed, 2011). Table 1 exhibits the proposed budget for all physical projects in developing the waqf in each of the state in Malaysia.

Table 1: Tenth Malaysian Plan Proposed Budget for Waqf Development

\begin{tabular}{|c|c|c|}
\hline State & Number of physical projects & Budgeted Funds (RM in mil) \\
\hline Kedah & 7 & 98 \\
\hline Penang & 8 & 275.25 \\
\hline Perak & 6 & 180 \\
\hline Kelantan & 7 & 140.5 \\
\hline Terengganu & 6 & 61 \\
\hline Pahang & 1 & 20 \\
\hline Selangor & 5 & 465 \\
\hline WP Persekutuan & 3 & 55 \\
\hline Negeri Sembilan & 8 & 99 \\
\hline Malacca & 5 & 88 \\
\hline Johor & 5 & 90 \\
\hline Sarawak & 3 & 105 \\
\hline Sabah & 1 & 100 \\
\hline Perlis & 3 & 50 \\
\hline Total & 68 & 1826.75 \\
\hline
\end{tabular}

Source: Ahmad \& Muhamed (2011)

\section{Governance and Efficiency}

Efficiency is one component in measuring the performance of an organization. It investigates how efficient an organization manages its operation and measures how much result is achieved given 
INTERNATIONAL JOURNAL OF ACADEMIC RESEARCH IN BUSINESS AND SOCIAL SCIENCES Vol. 10, No. 10, 2020, E-ISSN: 2222-6990 @ 2020 HRMARS

certain input. From the business perspective, efficiency is making the comparison between consumption of the resources and the production of goods. In this way, the performance of an organization can be measured by looking at its productivity level.

The data envelopment analysis (DEA) is used to asses performance of many different industries in many different countries. There are studies using DEA in banking, transportation, charities, municipal and many more. All these studies found that DEA is the solution to the difficulties in weighing multiple inputs and outputs in other approaches such as stochastic frontier analysis (SFA). DEA makes inefficiency estimation possible in recognizing efficient DMUs and use them to improve other inefficient DMUs. Sufian (2007a) wrote that the DEA is superior over the stochastic frontier analysis (SFA) since it demands minimal data and works well with small sample sizes. Apart from this, the DEA assigns single efficiency score for each DMU in ranking the DMU in the sample. On a different aspect, it detects the level of inputs utilization and outputs production by focusing on the areas of improvement for each DMU under study. Finally, the DEA can be used to make inferences on the DMUs' general profile.

Therefore, pure technical efficiency (PTE) is linked to the managerial aspect of an organization and help the management to impose any decision as appropriate. Meanwhile, the scale efficiency (SE) is associated to the size of operation of an organization. Annim (2012) analyzed 164 panel data of the world MFIs which showed the trend of the PTE against the SE. His study showed that the PTE is greater than the SE. There was an increasing upward trend in the PTE scores in contrast to the SE scores. Similarly, Kipesha (2012) studied the technical efficiency (TE) of MFIs based on the assumptions of the CRS and VRS using CCR and BCC DEA model in obtaining the PTE and SE scores. He found that the MFIs have higher PTE scores than the SE scores. In another study, Maamor and Ismail (2010) discovered that the efficiency scores are different when calculated under different scale of returns. The PTE scores under the VRS and CRS assumptions were greater than the SE scores.

In contrast, Sufian (2007a) study of the technical efficiency of domestic and foreign banks uncovered that the PTE scores of the DMUs under study outperformed the SE scores. The SE scores of both bank types suggest that source of inefficiency is highly connected to the scale size of the banks. Sufian (2007a) study is in tandem with Ahmad and Abdul Rahman (2012) who posited that the Islamic banks as a whole have problems in operating under the optimum scale size as evidenced by the lower SE in comparison to higher PTE. Relatedly, Abd Wahab and Abdul Rahman $(2011 ; 2012 ; 2013)$ revealed that the SE scores is higher than the PTE scores suggesting that the technical inefficiency of zakat institutions may be due to technical aspects rather than size of the institutions. Even Rosman, Abd Wahab and Zainol (2013) agreed that the scale efficiency overshadowed the pure technical efficiency. Thus, the following hypothesis is established:

H1: Pure technical efficiency (PTE) highly contributes to the inefficiency of the SIRCs in managing waqf in Malaysia.

In addition, the study will also examine the corporate governance mechanisms such as board size, board independence and board meeting as efficiency determinants for the second stage analysis. There is no certain conclusion as to how many directors should serve in the board of directors. Some 
INTERNATIONAL JOURNAL OF ACADEMIC RESEARCH IN BUSINESS AND SOCIAL SCIENCES Vol. 10, No. 10, 2020, E-ISSN: 2222-6990 @ 2020 HRMARS

researchers such as Shivdasani and Yermack (1999) and Vafeas (1999) recommended a number of 11 or 12 directors as sufficient. Differently, Jensen (1993) and Haniffa and Hudaib (2006) agreed that the number of directors should be confined to eight. For them, the number of eight directors makes decision making process efficient and easy. Evidently, previous studies indicated that there is a mixed result in the direction of the relationship between the board size and efficiency. García-Sánchez (2010) found there exists different direction in the relationship of the board size and technical efficiency of the public and private firms in Spain. While, Callen, Klein and Tinkelman (2003) and Andres-Alonso, Azofra-Palenzuela and Romero-Merino (2010) found that there is a negative relationship between board size and efficiency of an organization. Therefore, the following hypothesis is established between the board size and efficiency of the SIRCs:

$\mathrm{H} 2$ : There is a negative relationship between board size and efficiency of the SIRCs in managing waqf in Malaysia.

Nanka-Bruce (2011) also posited that if the board independence is highly dominant, it can have a negative effect on efficiency. As such, board independence can be detrimental to the efficiency of the organization. Further evidence of the negative relationship between board independence and efficiency include studies done by O' Regan and Oster (2005) and Lin, Ma and Su (2009). In addition, Aggrawal and Knoeber (1996) and Klein, Shapiro and Young (2004) agreed that board independence can be detrimental to the efficiency of the organization. However, Bozec and Dia (2007), Chan and Heang (2010) and Nanka-Bruce (2011) found positive relationship between board independence and efficiency, particularly in the monitoring the management decision and protecting the shareholders' interest as well as the organization's reputation. In tandem with the studies above, the relationship between board independence and efficiency of the SIRCS is assessed through the following hypothesis:

$\mathrm{H} 3$ : There is a negative relationship between board independence and efficiency of the SIRCS in managing waqf in Malaysia.

Rebeiz and Salameh (2006) and Saleh, Iskandar and Rahmat (2005) found there is no significant relationship between board meeting and efficiency. The amount of meetings per year does not indicate that board of directors are able to develop and improve the efficiency of an organization. For them, the most important is the quality of the meetings and its capability of producing the decision and action. Nevertheless, the board meetings are mandatory for most organization and it is also compulsory for them to disclose the number of meetings in their annual report. In agreement to this, Gulzar and Wang (2011) indicated that frequent board meetings intensifies the board activeness in monitoring the management activities of the organization. His argument is supported by Lipton and Lorsch (1992), Evans and Weir (1995), Conger et al. (1998) and Andres, Azofra and Lopez (2005) who pointed that the frequent number of meeting will increase the efficiency of an organization. Therefore, the relationship between board meetings and efficiency is established as follows:

$\mathrm{H} 4$ : There is a positive relationship between the number of board meeting and efficiency of the SIRCs in managing waqf in Malaysia

\section{Location, Size and Efficiency}

To strengthen the result of the analysis, this study will include the location and size of the SIRCs. The studies by Luo (2003), Johnes and Yu (2008) and Said (2012) agree that there is no relation between 
INTERNATIONAL JOURNAL OF ACADEMIC RESEARCH IN BUSINESS AND SOCIAL SCIENCES Vol. 10, No. 10, 2020, E-ISSN: 2222-6990 @ 2020 HRMARS

location and efficiency. Using several tests using Kruskal-Wallis and median test, Luo (2003) examined the relationship between location and efficiency. They detected that there is no significant relationship between location and efficiency of 254 large banks in the United States for the 2000. Subsequently, Johnes and $\mathrm{Yu}$ (2008) observed that there is no significant relationship between location and efficiency of 100 Chinese higher education institutions (HEIs) for the year 2003-2004. On the same ground, Said (2012) disclosed that banks in different locations showed no significant relationship in their efficiency scores for the year 2006 to 2009.

On the contrary, Miller and Noulas (1996) found that location does affect the efficiency of 201 large banks in the United States from the year 1984-1990 where the Mideast states showed a higher efficiency scores in comparison to the Southeast and Northeast states. In supportive of Miller and Noulas (1996) and Lin and Hong (2006), Paradi, Rouatt and Zhu (2011) opined that location may have some influence on the efficiency measurement of organizations. They reckoned that a strong variation is evidenced from the analysis of 816 bank branches of different location in Canada. Based on these past studies, the following hypothesis is proposed.

$\mathrm{H} 5$ : There is a positive relationship between location and efficiency of the SIRCs in managing waqf in Malaysia.

On another factor, Yuengert (1993), Miller and Noulas (1996), Kwan (2006), Lin and Hong (2006), Sufian (2007b), Luhnen (2009), Eling and Luhnen (2010), Gulati (2011), Said (2012) and Cummins and Xie (2013) pondered into the effect of size of organization and efficiency. Kwan (2006) reported a negative relationship between size and efficiency of banks. On another hand, Gulati (2011) recorded a mixed result of the relationship between size and efficiency where he found no significant relationship in the TE and PTE scores based on the different sizes of the banks. On the other hand, he observed that there is a significant relationship between scale efficiency scores and bank sizes specifically in the case of large and medium size banks. In a much later study, Said (2012) concocted that the relationship between size and efficiency shows no significant relationship in the efficiency of the banks with large banks and small to medium banks in India.

However, Sufian (2007b) studied the relationship between the size (total assets) and efficiency of Malaysian Islamic banks. To test the consistency of his result, he performed the Spearman and Pearson correlation coefficient as the second stage analysis to test the relationship between size (total asset) and efficiency of the banks. He discovered that there is significant positive relationship between size and efficiency of the banks. The studies by Yuengert (1993), Luhnen (2009), Eling and Luhnen (2010) and Cummins and Xie (2013) are also in agreement that there is a positive relationship between size and efficiency. As such, the next hypothesis is:

H6: There is a positive relationship between size and efficiency of the SIRCs in managing waqf in Malaysia.

\section{Methods}

\section{Sample and Data Collection}

This study collected the information pertaining from previous publications, books, magazines, research papers, internet homepage and other relevant data that are important to the study. In addition, interview sessions are conducted with the selected waqf institutions as to have a clear 
INTERNATIONAL JOURNAL OF ACADEMIC RESEARCH IN BUSINESS AND SOCIAL SCIENCES Vol. 10, No. 10, 2020, E-ISSN: 2222-6990 @ 2020 HRMARS

understanding of how the waqf in Malaysia are managed. This study uses panel data taken from the SIRCs' annual reports from year 2007 till 2013. The data will cover all the waqf entrusted to the SIRCs. The total number of samples is 13 which consists of all 13 SIRCs in Malaysia. To be consistent with the DEA's lenient rule of thumb, as supported by Golany \& Roll (1989), the number of DMU must at least equal to twice the combined number of inputs and outputs.

\section{Selection of Input and Output Variables}

The success in assessing the efficiency of DMUs depended heavily on the specification of inputs and outputs used in its measurement. It is worth to point that the choices of variables are in tandem with the management objectives of reducing costs in achieving maximum income from the waqf. As such, the number of elements must be kept objectively reasonable which points to the DEA's rule of thumb where Golany and Roll (1989) stated that the number of DMUs must at least equal to twice the combined number of inputs and outputs. The selected inputs and outputs used for the assessment and analysis of the SIRCs' efficiency is displayed in Table 2.

Table 2: Inputs and Outputs used in Generating Efficiency Scores

\begin{tabular}{ll}
\hline Inputs & Proxies/Measurement \\
\hline Labor (L) & $\begin{array}{l}\text { Salary expenses in RM (Maamor \& Ismail, } \\
\text { 2010) } \\
\text { Operating expenses minus the salary } \\
\text { Operating expenses (OE) }\end{array}$ \\
$\begin{array}{l}\text { Rahman, 2011; 2012) } \\
\text { Fixed Assets in RM (Sufian, 2007b) }\end{array}$ \\
\hline Outputs & Proxies/Measurement \\
\hline Rental Income (RI) & Total Rental Income in RM (Noor \& \\
& Ahmad, 2012) \\
Investment Income (II) & Total Investment Income in RM (Ahmad \& \\
& Abdul Rahman, 2012). \\
\hline
\end{tabular}

\section{Two Steps Analysis}

Two stages are involved in structuring the framework for the analysis of the efficiency of the SIRCs. The first stage is to estimate the SIRCs' efficiency using data envelopment analysis (DEA) via PIM-DEA 3.2 and the other is finding the factors that influence the efficiency using Ordinary Least Square (OLS) analysis via EVIEWS 9 software (Bhattacharyya, Lovell and Sahay, 1997; Isik and Hassan, 2002; Xu, 2011; Gulati, 2011; and Noor and Ahmad, 2012).

\section{First Stage: Data Envelopment Analysis (DEA)}

The emphasis of using DEA in this thesis is not due to its capability of analyzing a DMU using a small sample size, but also the concept of relative efficiency is vital in attaining the research objectives of this study. DEA was first introduced by Charnes, Cooper and Rhodes (1978) to measure the efficiency of each DMU by comparing its inputs and outputs to those of others in the same business. Connectively, these inputs referred to the resources used while the outputs correspond to the result from the production process. There are two models of DEA applied to this current study. 
INTERNATIONAL JOURNAL OF ACADEMIC RESEARCH IN BUSINESS AND SOCIAL SCIENCES Vol. 10, No. 10, 2020, E-ISSN: 2222-6990 @ 2020 HRMARS

A simple efficiency ratio model for $n$ number of DMUs with each DMU producing $s$ different outputs using $r$ different inputs is expressed in Equation 1 (Cunha Robiera, 1999).

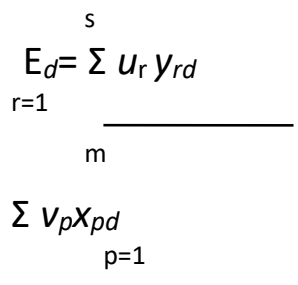

Equation 1

where:

$E_{d}=$ relative efficiency of the DMUd

$\mathrm{S} \quad=$ number of outputs produced by DMUd

$\mathrm{m}$ = number of inputs utilized by DMUd

$\mathrm{y}_{\mathrm{r}} \quad$ = the $\mathrm{r}$ th output produced by DMUd

$x_{p} \quad=$ the $p$ th input utilized by DMUd

$u_{r}=s \times 1$ vector output weights

$v_{p}=m \times 1$ vector inputs weights

and

$r=1, \ldots . s$

$\mathrm{p}=1, \ldots \mathrm{m}$

In order to take into account the present of constant returns to scale and presumes all inputs are controllable by the DMU, Equation 1 is adjusted as expressed by Equation 2.

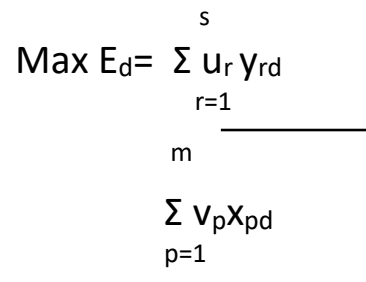

Equation 2

subject to

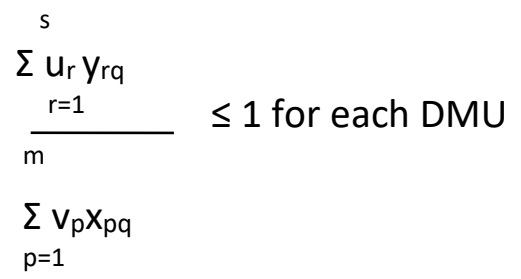

where, observed performance $q=1, \ldots . . n$ (number of DMUs) 
INTERNATIONAL JOURNAL OF ACADEMIC RESEARCH IN BUSINESS AND SOCIAL SCIENCES Vol. 10, No. 10, 2020, E-ISSN: 2222-6990 @ 2020 HRMARS

To get the most efficiency level of the DMU $d$, the ratio of weighted outputs $\left(u_{r}\right)$ to weighted inputs $\left(v_{p}\right)$ is optimized but only when efficiency measures of the rest of DMUs must be less than or equal to unity provided that same weights are chosen. The best possible efficiency result of $d$ is then obtained by choosing weights without setting any priori. However, the DMU may encountered some problem in assigning weights to the inputs and outputs since different DMU may have different valuation in choosing the inputs and output weights. Therefore, the CCR model eliminates this problem by allowing the DMU to acquire a set of weights that will maximize its relative efficiency which is not the same as other DMUs.

CCR Model: Technical Efficiency

Charnes et al. (1978) introduced the term Data Envelopment Analysis (DEA) where each DMU's efficiency is measured by taking a maximum ratio of weighted output to weighted input. They transformed Equation 2 into a linear programming problem as to solve the hardship putting weights in the fractional program. The new model is solely expressed in terms of weight by making algebraic replacement of all efficiency variables with optimization problems. An extra restriction is also imposed where the denominator of the objective function is set to 1 . The efficiency of a DMU can be determined from input orientation or output orientation of the CCR model. Input orientation refers to the fullest minimization the inputs can be utilized while maintaining the same output level while output orientation signifies the maximization of the output by making alteration to the inputs. Both orientations in the CCR model are depicted in Equation 3 and Equation 4.

Input orientation model:

$$
\operatorname{Max}_{d}=\sum_{r=1}^{s} u_{r} y_{r d}
$$

Equation 4.3

subject to:

$$
\begin{aligned}
& \sum_{p=1}^{m} v_{p} x_{p d}=1 \\
& \sum_{r=1}^{s} u_{r} y_{r q}-\sum_{p=1}^{m} v_{p} x_{p q} \leq 0
\end{aligned}
$$

$q=1, \ldots n$ and $u_{r}, v_{p} \geq 0$ ( $u$ and $v$ are small but holds positive quantity)

Output orientation model:

$$
\operatorname{MinF}_{d}=\sum_{p=1}^{m} v_{p} x_{p q} \quad \text { Equation } 4
$$

subject to:

$$
\begin{aligned}
& \sum_{r=1}^{s} u_{r} y_{r q}=1 \\
& \sum_{r=1}^{s} u_{r} y_{r q}-\sum_{p=1}^{m} v_{p} x_{p q} \leq 0
\end{aligned}
$$


INTERNATIONAL JOURNAL OF ACADEMIC RESEARCH IN BUSINESS AND SOCIAL SCIENCES

Vol. 10, No. 10, 2020, E-ISSN: 2222-6990 @ 2020 HRMARS

$q=1, \ldots n$ and $u_{r}, v_{p} \geq 0$ ( $u$ and $v$ are small but holds positive quantity)

For the above linear programming problems, the duality of the objective function can be conveyed in Equation 5

$$
\text { Minz } z_{d}=\sum_{p=1}^{m} z_{d} x_{p d} \quad \text { Equation } 5
$$

subject to:

$$
\begin{aligned}
& \sum_{q=1}^{N} \phi_{q} y_{r q} \geq y_{r d}, r=1, \ldots . . s \\
& z_{d} x_{p d}-\sum^{N} \phi_{q} x_{p q} \geq 0, p=1, \ldots . m ; \phi_{q} \geq 0 ; 0<z_{d}<1
\end{aligned}
$$

where, $\varnothing$ is $n \times 1$ vector of constant and $N$ refers to the number of times the linear programming be repeated on other DMU in the sample.

The technical efficiency (TE) also known as overall technical efficiency (OTE) is represented by $z_{d}(a$ scalar) of the $d$-th DMU where its value must be between 0 and 1 . If the score of 1 is obtained, the DMU is considered fully and technically efficient. This matches the definition of efficiency by Farrell (1957).

\section{BCC Model: Pure Technical Efficiency}

The CCR model presupposes that the DMUs are operating at an optimal scale but in practice, it is almost impossible to operate at the optimal scale. By assuming that all DMUs are operating at optimal scale will contaminate the technical efficiency with scale efficiencies. As such, the CCR model was further refined by Banker et al. in 1984 to represent the variable return to scale element in the linear programming by adding convexity condition in assessing the efficiency performance of DMU. The convexity, $\emptyset_{\mathrm{q}}$ is now constraint to 1 as shown in Equation 4.6.

$$
\sum \phi_{q}=1 \quad \text { Equation } 6
$$

By adding the convexity constraint to 1 , this new model is called BCC model as it is introduced by Bankers, Charnes and Cooper in 1984. The efficiency scores obtained from BCC is now known as pure technical efficiency (PTE) where VRS is permitted while discarding the scale part in the analysis. As with CCR model, assessment of efficiency using the BCC model also can be done under input orientation or output orientation as shown in Equation 7 and 8.

Input orientation model

$$
\operatorname{MaxE}_{d}=\sum_{r=1}^{s} u_{r} y_{r d}-w_{d} \quad \text { Equation } 7
$$


INTERNATIONAL JOURNAL OF ACADEMIC RESEARCH IN BUSINESS AND SOCIAL SCIENCES

Vol. 10, No. 10, 2020, E-ISSN: 2222-6990 @ 2020 HRMARS

subject to:

$\sum_{p=1}^{m} v_{p} x_{p d}=1$

$\sum_{r=1}^{s} v_{r} x_{r d}-\sum_{p=1}^{m} v_{p} x_{p q}-w_{d} \leq 0$

$q=1, \ldots n$ and $u_{r}, v_{p} \geq 0$ ( $u$ and $v$ are small but holds positive quantity)

Output orientation model:

$$
\operatorname{MinF}_{d}=\sum_{p=1}^{m} v_{p} x_{p q}+w_{d}
$$

Equation 8

subject to:

$\sum_{r=1}^{s} u_{r} y_{r q}=1$

$\sum_{r=1}^{s} u_{r} y_{r q}-\sum_{p=1}^{m} v_{p} x_{p q}-w_{d} \leq 0$

$\mathrm{q}=1, \ldots \mathrm{n}$ and $\mathrm{u}_{r}, \mathrm{v}_{p} \geq 0$ ( $\mathrm{u}$ and $\mathrm{v}$ are small but holds positive quantity)

The $w_{d}$ is the unrestricted parameter that specifies various possibility of return to scale which comprises of increasing return to scale $\left(w_{d}>0\right)$, constant return to scale $\left(w_{d}=0\right)$ and decreasing return to scale $\left(w_{d}<0\right)$. Due to the joining of the level surface formed by the hull convex, the data points in this model are more tightly enclosed compared to the CCR model. This will grant the efficiency scores obtained from BCC model higher than efficiency scores from the CCR model.

The dual function for the BCC model is formulated as in Equation 9.

$$
\operatorname{Min} Z_{d}=\sum_{p=1}^{m} z_{d} x_{p d}
$$

Equation 9

subject to

$$
\begin{aligned}
& \sum_{q=1}^{N} \phi_{q} y_{r q} \geq y_{r d}, r=1, \ldots . S \\
& z_{d} x_{p d}-\sum^{N} \phi_{q} x_{p q} \geq 0, p=1, \ldots . m ; \phi_{q} \geq 0 ; 0<\mathrm{z}_{d}<1 \\
& \sum \phi_{q}=1, q=1, \ldots . \sum \phi_{q}=1, \ldots . N
\end{aligned}
$$


where, $\varnothing$ is $\mathrm{n} \times 1$ vector of constant and $\mathrm{N}$ refers to the number of times the linear programming be repeated on other DMU in the sample.

As we can see, the Equation 9 is similar to Equation 5 except for the presence of $\Sigma \varnothing q=1$ as the convexity constraint. With this convexity constraint, the scale optimization in CCR model is slackened. Noticeably, the BCC model allows only the technical efficiency devoid of scale is measured hence the name pure technical efficiency corresponds to it.

Conceptually, the big different between the CCR model and BCC model lies in the interpretation of the efficiency measurement. The former suggested that a DMU is deemed efficient when it achieves scale and technical efficiency. On the other hand, the latter presumes that a DMU is viewed as efficient by just looking at its technical efficiency devoid of its scale efficiency.

Scale Efficiency Model

If a DMU's efficiency score obtained from both the CCR and BCC model is equal to 1 , it is considered to be fully efficient and assumed to be operating at the optimal scale. However, if its efficiency scores from CCR model are low compared to scores from BCC model, it is considered technically efficient but not purely technically efficient due to the presence of scale size of the DMU. It is therefore justifiable to distinguish the scale efficiency of a DMU by dividing the CCR score to the BCC score (Cooper, Seiford \& Tone, 2000). The ratio is shown in Equation 10.

$$
S E=\frac{T E}{P T E} \quad \text { Equation } 10
$$

From Equation 10, the relationship between TE, PTE and SE can be established into Equation 11.

$$
T E=P T E \times S E
$$

$$
T E=P T E \times S E \quad \text { Equation } 11
$$

The sources of inefficiency can be identified through the decomposition of TE into PTE and SE. PTE corresponds to operating efficiency while SE relates to scale size of the DMU under assessment. Maamor and Ismail (2010) further mentioned that by identifying the return to scale of a DMU, it is able to decide whether to improve its performance through reducing or increasing its size.

\section{Second Stage: Panel Data Analysis}

The objectives of this study is to find the factors that may contribute to the efficiency level of the SIRCs. To do this, the TE scores from DEA treated as the dependent variable is regressed against the determinants as the independent variables by using EVIEW 9 software. In this case, the determinants are geographical location (LOC), size of organization (SIZE), board size (BS), board independence (BI) and board meeting (BM). It is hopeful that by investigating into these determinants, a DMU can successfully improve their efficiency performance. 
INTERNATIONAL JOURNAL OF ACADEMIC RESEARCH IN BUSINESS AND SOCIAL SCIENCES Vol. 10, No. 10, 2020, E-ISSN: 2222-6990 @ 2020 HRMARS

In the first stage of analysis, DEA method is used to calculate efficiency scores of the SIRCs. For the regression analysis, OLS analysis seems appropriate as proven by many studies that employed the OLS analysis. Some of the studies that apply OLS in their study are Saleh, Iskandar and Rahmat (2005), Bozec and Dia (2007), Johari, Saleh and Hassan (2008) and Gulzar and Wang (2011). The OLS is a simplified linear modeling method to test the relationship between one dependent variable to two or more independent variables (Hutcheson, 2011). Thus, this study will utilize OLS since there are more than one explanatory variables to predict one dependent variable. Specifically, this study will use panel pool regression model to determine the correlation between the dependent and independent variables. In a way, the appropriate method is to use the pooled OLS, fixed and random effect to choose the best fit model of the study. For this intention, Correlated Random EffectsHausman Test will be applied to show the significance of the Fixed and Random Effects model (Anderson \& Reeb, 2003)

Equation 12 specifies the model that will be used to analyze the relationship between the independent variables (location [LOC], size of organization [SIZE], board size [BS], board independence $[\mathrm{BI}]$ and board meeting $[\mathrm{BM}]$ ) and the dependent variable (efficiency [Eff]).

$E f f=\alpha 0+\beta 1 L O C+\beta 2 S I Z E+\beta 3 B S+\beta 4 B I+\beta 5 B M+\varepsilon$

Equation 12

\section{Results}

\section{Descriptive Statistics of the Input and Output}

Table 3 displays the descriptive statistics for the inputs and outputs for this study. In specific, it gives details of the average, minimum and maximum amount of the inputs and outputs used by the 13 SIRCS and how diverse are the amount of inputs and outputs among the 13 SIRCs. 
INTERNATIONAL JOURNAL OF ACADEMIC RESEARCH IN BUSINESS AND SOCIAL SCIENCES Vol. 10, No. 10, 2020, E-ISSN: 2222-6990 @ 2020 HRMARS

Table 3: SIRCs Descriptive Statistics of Inputs and Outputs (2007-2013)

\begin{tabular}{|c|c|c|c|c|}
\hline & Mean & Minimum & Maximum & $\begin{array}{l}\text { Standard } \\
\text { Deviation }\end{array}$ \\
\hline \multicolumn{5}{|l|}{ Input: } \\
\hline $\begin{array}{l}\text { Salary } \\
\text { Expenses } \\
\text { (RM) }\end{array}$ & 115,348 & 7,083 & 472,763 & 91,654 \\
\hline $\begin{array}{l}\text { Other } \\
\text { operating } \\
\text { Expenses } \\
\text { (RM) }\end{array}$ & 126,357 & 692 & 553,686 & 130,589 \\
\hline $\begin{array}{l}\text { Fixed Assets } \\
\text { (RM) }\end{array}$ & $5,765,101$ & 24,931 & $78,100,200$ & $10,257,493$ \\
\hline \multicolumn{5}{|l|}{ Output: } \\
\hline $\begin{array}{l}\text { Investment } \\
\text { Income } \\
\text { (RM) }\end{array}$ & 132,985 & 1,558 & 643,928 & 143,906 \\
\hline $\begin{array}{l}\text { Rental } \\
\text { Income } \\
\text { (RM) }\end{array}$ & 328,615 & 2,089 & $2,148,702$ & 394,661 \\
\hline
\end{tabular}

On the average, there is a wide range between the minimum and maximum amount of inputs used and outputs produced by all 13 SIRCs as shown in Table 3. In this particular case, the different demographic characteristics justify the vast gap in the minimum and maximum value of the inputs and outputs used in this study. The value of the inputs and outputs available in the SIRCs depend on the population of each state. For example, Perlis is a small state with a population of 204,000 in 2010 (Department of Statistic, 2010). Therefore, it is expected that the value of the inputs and outputs are much less in comparison to the rest of the SIRCs in Malaysia. On the other hand, Selangor is a bigger state than Perlis with a population of three million people. Ironically, its inputs and outputs are less than states such as Kelantan and Terengganu. Based on the Department of Statistic (2010), Kelantan and Terengganu reported a lower amount of population (1,465,388 and 1,004,152, respectively) have a higher percentage of Muslim population (95.2 percent and 96.90 percent, respectively) than Selangor. They display a big chunk of values of inputs used and outputs produced among the 13 SIRCS with an average of total inputs and outputs at RM2,439,336 and RM4,897,629, correspondingly.

\section{Decomposition of TE: PTE and SE}

Based on Table 4, the TE score of the 13 SIRCs for the year 2007 to 2013 are found to be the highest in 2012 (69.4 percent), while the lowest TE score is in year 2008 (52.4 percent). On the other hand, the PTE score is the lowest in 2010 (61.6 percent) while the highest PTE score is in year 2011 (79.2 percent). 
INTERNATIONAL JOURNAL OF ACADEMIC RESEARCH IN BUSINESS AND SOCIAL SCIENCES Vol. 10, No. 10, 2020, E-ISSN: 2222-6990 @ 2020 HRMARS

Table 4: Summary of Efficiency Scores Statistics (2007-2013)

\begin{tabular}{|c|c|c|c|c|c|}
\hline SIRC & Mean & Minimum & Maximum & $\begin{array}{c}\text { Std } \\
\text { Deviation }\end{array}$ & $\begin{array}{c}\text { Percentage } \\
\text { of } \\
\text { Inefficiency } \\
(\%)\end{array}$ \\
\hline \multicolumn{6}{|c|}{ Panel A: All SIRCs 2007} \\
\hline Technical Efficiency & 0.539 & 0.041 & 1.000 & 0.364 & 46.1 \\
\hline Pure Technical & 0.633 & 0.110 & 1.000 & 0.338 & 36.7 \\
\hline Efficiency & 0.825 & 0.237 & 1.000 & 0.292 & 17.5 \\
\hline \multicolumn{6}{|l|}{ Scale Efficiency } \\
\hline \multicolumn{6}{|c|}{ Panel A: All SIRCs 2008} \\
\hline Technical Efficiency & 0.524 & 0.046 & 1.000 & 0.376 & 47.6 \\
\hline Pure Technical & 0.621 & 0.155 & 1.000 & 0.377 & 37.9 \\
\hline $\begin{array}{l}\text { Efficiency } \\
\text { Scale Efficiency }\end{array}$ & 0.817 & 0.266 & 1.000 & 0.268 & 18.3 \\
\hline \multicolumn{6}{|c|}{ Panel A: All SIRCs 2009} \\
\hline Technical Efficiency & 0.586 & 0.080 & 1.000 & 0.340 & 41.4 \\
\hline Pure Technical & 0.666 & 0.159 & 1.000 & 0.339 & 33.4 \\
\hline Efficiency & 0.854 & 0.500 & 1.000 & 0.175 & 14.6 \\
\hline \multicolumn{6}{|l|}{ Scale Efficiency } \\
\hline \multicolumn{6}{|c|}{ Panel A: All SIRCs 2010} \\
\hline Technical Efficiency & 0.539 & 0.106 & 1.000 & 0.358 & 46.1 \\
\hline Pure Technical & 0.616 & 0.154 & 1.000 & 0.348 & 38.4 \\
\hline Efficiency & 0.851 & 0.400 & 1.000 & 0.185 & 14.9 \\
\hline \multicolumn{6}{|l|}{ Scale Efficiency } \\
\hline \multicolumn{6}{|c|}{ Panel A: All SIRCs 2011} \\
\hline Technical Efficiency & 0.656 & 0.175 & 1.000 & 0.316 & 34.4 \\
\hline Pure Technical & 0.792 & 0.236 & 1.000 & 0.238 & 20.8 \\
\hline Efficiency & 0.809 & 0.283 & 1.000 & 0.233 & 19.1 \\
\hline \multicolumn{6}{|l|}{ Scale Efficiency } \\
\hline \multicolumn{6}{|c|}{ Panel A: All SIRCs 2012} \\
\hline Technical Efficiency & 0.694 & 0.122 & 1.000 & 0.383 & 30.9 \\
\hline Pure Technical & 0.773 & 0.136 & 1.000 & 0.331 & 22.7 \\
\hline Efficiency & 0.847 & 0.351 & 1.000 & 0.217 & 15.3 \\
\hline \multicolumn{6}{|l|}{ Scale Efficiency } \\
\hline \multicolumn{6}{|c|}{ Panel A: All SIRCs 2013} \\
\hline Technical Efficiency & 0.661 & 0.138 & 1.000 & 0.375 & 33.9 \\
\hline Pure Technical & 0.755 & 0.177 & 1.000 & 0.345 & 24.5 \\
\hline $\begin{array}{l}\text { Efficiency } \\
\text { Scale Efficiency }\end{array}$ & 0.853 & 0.330 & 1.000 & 0.221 & 14.7 \\
\hline
\end{tabular}

Table 4 further indicates that all 13 SIRCs are not efficient for the seven years with the TE scores range from 52.4 percent to 69.4 percent. The SIRCs obtained higher SE scores ranging from 80.9 percent to 85.4 percent with scale inefficiency of 14.6 percent to 19.1 percent. In contrast, the PTE scores of the 
INTERNATIONAL JOURNAL OF ACADEMIC RESEARCH IN BUSINESS AND SOCIAL SCIENCES Vol. 10 , No. 10, 2020, E-ISSN: 2222-6990 @ 2020 HRMARS

13 SIRCs for the seven years range from 61.6 percent to 79.2 percent. On the average, this suggests that the inefficiency of SIRCs in Malaysia might be caused by the managerial inefficiency as the main source of inefficiency of the SIRCs.

According to Abd Wahab and Abdul Rahman (2011), they concluded that the lower PTE indicates size does not play a major role in the zakat institutions efficiency in Malaysia consistent with the findings by Gulati (2011) and Noor and Ahmad (2012) who found that the lower PTE scores may points to the inefficiency of the managerial aspects. They concluded that size does not contribute to the overall efficiency of the SIRCs. Therefore, the finding of this study supported the hypothesis H1.

\section{Second Stage Analysis: Panel Data Analysis}

Instead of generating the efficiency scores of the SIRCs, this study also emphasizes other factors that may explain the differences in efficiency scores among the 13 SIRCs. By investigating the efficiency scores will not be viable since the DEA techniques produces efficiency scores bounded by 0 to 1.000 . Therefore, it is essential to perform a second stage analysis. For this study, the explanatory variables selected in determining the efficiency of the SIRCs are location (LOC), size of organization (SIZE), board size (BS), board independence (BI) and board meeting (BM). All these variables are regressed against the efficiency scores of the SIRCS as denoted by the technical efficiency (TE), pure technical efficiency (PTE) and scale efficiency (SE).

For the second stage analysis, only 10 SIRCs are used for the year 2007 to 2013 due to the unavailability of data for Sabah, Sarawak and Kedah. Table 5 shows the descriptive statistics for all variables used.

Table 5: Descriptive Statistics for all the Variables (2007-2013)

\begin{tabular}{cccc}
\hline & Minimum & Maximum & Mean \\
\hline TE & 0.264 & 0.984 & 0.576 \\
PTE & 0.291 & 1.000 & 0.687 \\
SE & 0.416 & 0.984 & 0.816 \\
LOC & 1 & 10 & 5.5 \\
SIZE & 1 & 3 & 1.6 \\
BS & 14 & 25 & 16.62 \\
BI & 78.95 & 88.42 & 84.29 \\
BM & 4 & 5 & 4.4
\end{tabular}

Note: Technical Efficiency (TE), Pure Technical Efficiency (PTE), Scale Efficiency (SE), Location (LOC), Board Size (BS), Board Independence (BI), Board Meeting (BM)

From Table 5, the mean for TE is at 57.6 percent for all 10 SIRCs. The lowest TE score is at 26.4 percent and the highest at 100 percent in optimizing their production scale. The lower average of TE indicate that most of the SIRCs do have problems in managing the resources of the waqf institutions as further evidenced by the lower mean for the PTE score of 68.7 percent in comparison to a higher mean SE score of $\mathbf{8 1 . 6}$ percent. The result further confirmed that the technical inefficiency of the SIRCs is due to inefficiency of the SIRCs in managing their resources. 
INTERNATIONAL JOURNAL OF ACADEMIC RESEARCH IN BUSINESS AND SOCIAL SCIENCES Vol. 10, No. 10, 2020, E-ISSN: 2222-6990 @ 2020 HRMARS

Table 6 presents the Spearman Rho correlation matrix for the dependent and independent variables of this study. The technical efficiency score carries a significant positive correlation with location at 1 percent level. Overall, the TE, PTE and SE show no significant correlation with the SIZE, BS, BI and BM except for the LOC.

Table 6: The Spearman Rho Correlation Matrix

\begin{tabular}{lcccccccc}
\hline Variables & TE & PTE & SE & LOC & SIZE & BS & BI & BM \\
\hline TE & 1.000 & & & & & & & \\
PTE & $0.767^{* *}$ & 1.000 & & & & & & \\
SE & $0.709^{*}$ & 0.448 & 1.000 & & & & & \\
LOC & 0.152 & $0.190^{*}$ & 0.188 & 1.000 & & & & \\
SIZE & 0.172 & -0.231 & 0.258 & -0.012 & 1.000 & & & \\
BS & 0.042 & 0.080 & 0.127 & 0.018 & 0.135 & 1.000 & & \\
BI & 0.139 & -0.166 & -0.067 & -0.612 & 0.234 & 0.370 & 1.000 & \\
BM & -0.211 & -0.370 & -0.198 & 0.136 & 0.509 & 0.111 & 0.285 & 1.000 \\
\hline
\end{tabular}

*** Significant at 0.01 level $* *$ Significant at 0.05 level * Significant at 0.10 level

Note: Technical Efficiency (TE), Pure Technical Efficiency (PTE), Scale Efficiency (SE), Location (LOC), Board Size (BS), Board Independence (BI), Board Meeting (BM)

\section{The Relationship between SIRCs' Efficiency and Its Determinants}

This section analyzes the empirical relationship between the LOC, SIZE, BS, BI and BM with the technical efficiency (TE), pure technical efficiency (PTE) and scale efficiency (SE) scores. Table 7 details all the variables by using the fixed effect model as the most appropriate model for this study. From the summary of the result, it is found that there is a positive and significant relationship between location and TE, PTE and SE. This positive relationship between location (as proxied by the GDP per capita) and efficiency is supported by Goldberg, Hanweck and Sugrue (1992), Samolyk (1992), Berger, Kashyap, Scalise, Gertler and Friedman (1995) and Lin and Hong (2006) hence, this result support the hypothesis $\mathrm{H} 2$.

Table 7: Fixed Effect Model for TE, PTE and SE

\begin{tabular}{lcccc}
\hline Variables & $\begin{array}{c}\text { Expected } \\
\text { Sign }\end{array}$ & $\begin{array}{c}\text { Technical } \\
\text { Efficiency }\end{array}$ & $\begin{array}{c}\text { Pure Technical } \\
\text { Efficiency }\end{array}$ & Scale Efficiency \\
\hline Intercept & & 59.84 & 63.006 & 33.840 \\
LOC & + & $23.333(6.761)^{* * *}$ & $9.014(5.327)^{* * *}$ & $3.102(2.502)^{* *}$ \\
SIZE & + & $2.670(0.569)$ & $2.937(0.135)$ & $1.857(2.440)^{* *}$ \\
BS & - & $-2.437(1.964)^{*}$ & $-9.997(1.982)^{*}$ & $-1.841(1.989)^{*}$ \\
BI & - & $-4.349(0.675)$ & $-7.744(1.979)^{*}$ & $-4.382(0.617)$ \\
BM & + & $1.818(0.781)$ & $11.828(0.649)$ & $2.773(0.616)$ \\
\hline $\mathrm{R}^{2}$ & & 0.470 & 0.237 & 0.682 \\
Adj. $\mathrm{R}^{2}$ & & 0.370 & 0.178 & 0.597 \\
\hline
\end{tabular}

$* * *$ Significant at 0.01 level $* *$ Significant at 0.05 level * Significant at 0.10 level Note: Technical Efficiency (TE), Pure Technical Efficiency (PTE), Scale Efficiency (SE), Location (LOC), Board Size (BS), Board Independence (BI), Board Meeting (BM) 
INTERNATIONAL JOURNAL OF ACADEMIC RESEARCH IN BUSINESS AND SOCIAL SCIENCES Vol. 10, No. 10, 2020, E-ISSN: 2222-6990 @ 2020 HRMARS

The result of the regression analysis further indicates that there is significant and positive relationship between size SE at 5 percent level. As evidenced from the return to scale analysis previously, the majority of the SIRCS are operating under the decreasing return to scale, Justifiably, Miller and Noulas (1996) did find that size has a positive relationship to efficiency where he stated that large institutions tend to operate under decreasing return to scale. Other studies that support the positive relationship between size and efficiency are Yuengert (1993), Sufian (2007b), Luhnen (2009), Eling and Luhnen (2010) and and Cummins and Xie (2013), thus support H3.

Regarding the board size, there is a significant and negative relationship with TE, PTE and SE at 10 percent level indicating that the larger the number of directors, the lower the efficiency of an organization and vice versa. In literal meaning, the organization with small number of directors will have the capacity to improve the efficiency level of an organization. According to Callen, Klein and Tinkel (2003), a large board size not only delay decision process but also increase cost. Even AndresAlonso, Azofra-Palenzuela and Romero-Merino (2010) and Abd Wahab and Abdul Rahman (2012) agree that there is a negative relationship between size and efficiency. As such, the result does support H4.

With regards to $\mathrm{BI}$, there is a negative and significant relationship between $\mathrm{BI}$ and PTE. This findings consistent with Aggrawal and Knoeber (1996), Klein, Shapiro and Young (2004), and Lin, Ma and Su (2009). They agreed that board independence can be detrimental to the efficiency of the organization. Therefore, the finding also does support H5. Meanwhile, the board meeting (BM) shows no significant relationship with efficiency of the SIRCs. Rebeiz and Salameh (2006) and Abd Wahab and Abd Rahman (2011) opined that the BM does not have significant influence of the efficiency of an organization. Therefore, the finding also does not support $\mathrm{H} 6$.

\section{Conclusion}

The empirical findings show that pure technical efficiency is more dominant in the inefficiency of the SIRCs which reflects that the SIRCs have problems in managing their resources or in optimizing their scale size of operation. This result is consistent with Gulati (2011), Abd Wahab and Abdul Rahman (2011) and Noor and Ahmad (2012) who agreed that the lower pure technical efficiency points to the inefficiency of an organization managing their resources. In addition, location, size of organization and board meeting do play an important role or determinants in the efficiency of the SIRCs which is consistent with a few studies such as Sufian (2007b) and Gulzar and Wang (2011). The significant findings between location and efficiency indicating that SIRCs at different location perform differently in terms of their efficiency since different location has different characteristic in terms of size of the state, income, economic development, population, technology and enactment. As for the size of the organization, there is a positive relationship to the efficiency of the SIRCs. Herewith, the bigger the size of the SIRCs, the more efficient is the SIRC. Respectively, it was found that the SIRCs' efficiency is not caused by scale efficiency but more to pure technical efficiency. As for the board size, the findings suggest that minimal number of board of directors will increase the efficiency of the SIRCs. At the same token, the finding exhibits that the smaller number of the board outsiders, the more efficient is the SIRCs. The suggestion for future research should extend the period of the study and apply all 13 SIRCs for the second stage analysis to have more accurate findings. 
INTERNATIONAL JOURNAL OF ACADEMIC RESEARCH IN BUSINESS AND SOCIAL SCIENCES Vol. 10, No. 10, 2020, E-ISSN: 2222-6990 @ 2020 HRMARS

From theoretical contribution, the Cobb Douglas Production concept as the foundation in discussing the economic theory on production performance. From there, the Farrell's efficient production concept and the performance frontier theory are also included to further explain the relationship between efficiency and production performance which is less discussion of these theories in the waqf performance studies. Hence, these outputs can be considered as a major contribution to the study of waqf efficiency and theory used in studying the efficiency of Islamic charitable organization such as the waqf institutions.

From empirical contribution, due to highly limited and scarce study on waqf performance empirically, this study can reduce the gap and this study is also the second attempt of investigating the waqf institution using DEA which differs from Hasan and Ahmad (2014) in the inputs and outputs combination. To this reason, this study provides reference for other researchers to undertake studies on the performance of the waqf institutions especially in the aspect of income generation. The application of DEA in the study of Islamic non-profit organization such as the waqf institution is limited. Hence, the method as utilized in this study can help other researchers to do more research on other Islamic non-profit organization.

\section{Acknowledgment}

The second author would like to thank Kementerian Pendidikan Malaysia and Universiti Sains Malaysia for granting a Fundamental Research Grant Scheme (FRGS), Grant No. 203.PMGT.6711698.

\section{References}

Abd Wahab, N., \& Abdul Rahman, A. R. A. (2011). A Framework to Analyse the Efficiency and Governance of Zakat Institutions. Journal of Islamic Accounting and Business Research, 2(1), 43-62.

Abd Wahab, N., \& Abdul Rahman, A. R. (2012). Efficiency of Zakat Institutions in Malaysia: An Application of Data Envelopment Analysis. Journal of Economic Cooperation and Development, 33 (1), 95-112.

Abd Wahab, N., \& Abdul Rahman, A. R. (2013). Determinants of Efficiency of Zakat Institutions in Malaysia: A Non-parametric Approach. Asian journal of Business and Accounting, 6 (2), 33-64.

Agrawal, A., \& Knoeber, C. R. (1996). The Performance and Mechanisms to Control Agency Problems between Managers and Shareholders. Journal of Financial and Quantitative Analysis, 31, 377-397.

Ahmad, S., \& Abdul Rahman, A. R. (2012). The Efficiency of Islamic and Conventional Commercial Banks in Malaysia. International Journal of Islamic and Middle Eastern Finance and Management, 5 (3), 241-263.

Ahmad, S., \& Muhamed, N. D. (2011). Wakaf dalam Agenda Pembangunan Ekonomi Negara di Malaysia. Jurnal Pengurusan JAWHAR, 5 (1), 63-81.

Alhabshi, S. O. (1991). Waqf management in Malaysia. In A. Mohamed (Ed.), Islam and the Economic Development of Southeast Asia: The Islamic Voluntary Sector in Southeast Asia (pp. 118-137). Institute of Southeast Asian Studies.

Anderson, R. C., \& Reeb, D. M. (2003). Founding-Family Ownership and Firm Performance: Evidence from the S \& P 500. The Journal of Finance, 58 (3), 1301-1328. 
INTERNATIONAL JOURNAL OF ACADEMIC RESEARCH IN BUSINESS AND SOCIAL SCIENCES Vol. 10, No. 10, 2020, E-ISSN: 2222-6990 @ 2020 HRMARS

Andres, P. D., Azofra, V., \& Lopez, F. (2005). Corporate Boards in OECD Countries: Size, Composition, Functioning and Effectiveness. Corporate Boards in OECD Countries, 13 (2), 197-211.

Andrés-Alonso, D., Azofra-Palenzuela, V., \& Romero-Merino, M. E. (2010). Beyond the Disciplinary Role of Governance: How Boards Add Value to Spanish Foundations. British Journal of Management, 21(1), 100-114.

Annim, S. K. (2012). Microfinance Efficiency: Trade-Offs and Complementarities between the Objectives of Microfinance Institutions and Their Performance Perspectives. European Journal of Development Research, 24 (5), 788-807.

Banker, R., Charnes, A., \& Cooper, W. W. (1984). Some Models for Estimating Technical and Scale Inefficiencies in Data Envelopment Analysis. Management Science, 30 (9), 1078-1092.

Berger, A. N., Kashyap, A. K., Scalise, J. M., Gertler, M., \& Friedman, B. M. (1995). The Transformation of the US Banking Industry: What a Long, Strange Trip It's Been. Brookings Papers on Economic Activity, 1995 (2), 55-218.

Bhattacharyya, A., Lovell, C. A. K., \& Sahay, P. (1997). The Impact of Liberalization on the Productive Efficiency of Indian Commercial Banks. European Journal of Operational Research, 98 (2), 332345.

Bozec, R., \& Dia, M. (2007). Board Structure and Firm Technical Efficiency: Evidence frOm Canada State-Owned Enterprises. European Journal of Operational Research, 177, 1734-1750.

Callen, J. L., Klein, A., \& Tinkelman, O. (2003). Board Composition, Committees and Organization Efficiency: The Case of Nonprofits. Nonprofits and Voluntary Sector, 32 (4), 493-520.

Chan, S. G., \& Heang, L. T. (2010). Corporate Governance, Board Diversity and Bank Efficiency: The Case of Commercial Banks in Malaysia. The Asian Business and Management Conference. Osaka, Japan.

Charnes, A., Cooper, W. W., \& Rhodes, E. (1978). Measuring Efficiency of Decision Making Units. European Journal of Operational Research, 2, 429-444.

Chowdhury, M. S. R., Chowdhury, I. A., Muhammad, M. Z., \& Yasoa, M. R. (2012). Problems of Waqf Administration and Proposals for Improvement: A Study in Malaysia. Journal of Internet Banking and Commerce, 17(1), 1-8.

Coelli, T. J., Rao, D. S. P., O'Donnell, C. J., \& Battese, G. E. (2005). An Introduction to Efficiency and Productivity Analysis. 2nd Edition. New York, Springer.

Conger, J. A., Finegold, D., \& Lawler III, E. E. (1998). Appraising Board Performance. Harvard Business Review, 136-148.

Cooper, W. W., Seiford, L. M., \& Tone, K. (2000). Data Envelopment Anaysis: A Comprehensive Text with Models, Application, References and DEA-Solver Software. Boston, USA: Kluwer Academics Publisher.

Cummins, J. D., \& Xie, X. (2013). Efficiency, Productivity, and Scale Economies in the U.S. PropertyLiability Insurance Industry. Journal of Productivity Analysis, 39 (2), 141-164.

Robiera, C. A. M. (1999). Performance Measurement and Improvement in the Bank Branch Networks using Data Envelopment Analysis. University of Warwick.

Department of Statistic Malaysia. (2010). Retrieved on 13 ${ }^{\text {th }}$ August, 2015 from http://www.statistics.gov.my.

Eling, M., \& Luhnen, M. (2010). Efficiency in the International Insurance Industry: A Cross-Country Comparison. Journal of Banking and Finance, 34 (7), 1497-1509. 
INTERNATIONAL JOURNAL OF ACADEMIC RESEARCH IN BUSINESS AND SOCIAL SCIENCES Vol. 10, No. 10, 2020, E-ISSN: 2222-6990 @ 2020 HRMARS

Evans, J., \& Weir, C. (1995). Decision Processes, Monitoring, Incentives and Large Firm Performance in the UK. Management Decision, 33(6), 32-38.

Farrell, M. (1957). The Measurement of Productive Efficiency. Journal of the Royal Statistical Society. Series A (General), 120 (3), 253-290.

Garcia-Sanchez, I. M (2010). The Effectiveness of Corporate Governance: Board Structure and Business Technical Efficiency in Spain. Central European Journal of Operation Research, 18, 311-339.

Golany, B., \& Roll, Y. (1989). An Application Procedure for DEA. Omega, 17 (3), 237-250.

Goldberg, L. G., Hanweck, G. A., \& Sugrue, T. F. (1992). Differential Impact on Bank Valuation of Interstate Banking Law Changes. Journal of Banking \& Finance, 16 (6), 1143-1158.

Gujarati, D. N., \& Porter, D. C. (2009). Basic Econometrics, $5^{\text {th }}$ Edition. New York: McGraw Hill-Irwin. Gulati, R. (2011). Evaluation of Technical, Pure Technical and Scale Efficiencies of Indian banks : An Analysis from Cross-sectional Perspective Estimation of Technical, Pure Technical and Scale Efficiencies of Indian banks : An Analysis from Cross-sectional Perspective. In The 13th Annual Conference on Money and Finance in the Indian Economy. Mumbai, India.

Gulzar, M. A., \& Wang, Z. (2011). Corporate Governance Characteristics and Earnings Management: Empirical Evidence from Chinese Listed Firms. International Journal of Accounting and Financial Reporting, 1 (1), 133-151.

Haniffa, R., \& Hudaib, M. (2006). Corporate Governance Structure and Performance of Malaysia Listed Companies. Journal of Business Finance and Accounting, 33 (7-8), 1034-1062.

Hasan, H., \& Ahmad, I. (2014). The Efficiency of Waqf Collection and Distribution of Malaysia State of Islamic Religion Councils (SIRCS): A Two-Stage Analysis. Recent Development Analysis and its Applications. Proceedings of the 12th International Conference of DEA. Kuala Lumpur, Malaysia.

Hasim, A. B. M. (2007). The Collection of Waqf through Insurance Companies: A Critical Analysis of the Malaysian Experience. Review of Islamic Economics, 11 (1): 63-74.

Hutcheson, G. D. (2011). Logistic Regression. In L. Moutinho and G. D. Hutcheson (Ed.), The SAGE Dictionary of Quantitative Management Research (173-175), Sage.

Isik, I., \& Hassan, M. K. (2002). Technical, Scale and Allocative Efficiencies of Turkish Banking industry. Journal of Banking \& Finance, 26(4), 719-766.

Ismail, C. Z., Salim N. J., \& Hanafiah, A. N. J (2015). Administration and Management of Waqf Land in Malaysia: Issues and Solutions. Mediterranean Journal of Social Sciences, 6 (4), 613-620

Jabatan Wakaf, Zakat dan Haji (JAWHAR). Retrieved from www.jawhar.gov.my.

Jabatan Wakaf, Zakat dan Haji (JAWHAR) Annual Report (2007-2013).

Jensen, M. (1993). The Modern Industrial Revolution, Exit, and the Failure of Internal Control Systems. Journal of Finance, 48, 831-880.

Johari, N. H., Saleh, N. M., \& Hassan, M. S. (2008). The Influence of Board Independence, Competency and Ownershipon Earnings Management in Malaysia. Journal of Economics and Management, 2, 281-306.

Johnes, J., \& Yu, L. (2008). Measuring the Research Performance of Chinese Higher Education Institutions Using Data Envelopment Analysis. China Economic Review, 19, 679-696.

Kipesha, E. F. (2012). Efficiency of Microfinance Institutions in East Africa : A Data Envelopment Analysis. European Journal of Business and Management, 4 (17), 77-88 
INTERNATIONAL JOURNAL OF ACADEMIC RESEARCH IN BUSINESS AND SOCIAL SCIENCES Vol. 10, No. 10, 2020, E-ISSN: 2222-6990 @ 2020 HRMARS

Klein, P., Shapiro, D. M., \& Young, J. (2004). Board Independence and the Family-Owned Firm. Canadian Investment Review, 17(13), 8-13.

Kwan, S. H. (2006). The X-efficiency of Commercial Banks in Hong Kong. Journal of Banking and Finance, 30 (4),1127-1147

Lin, L. C., \& Hong, C. H. (2006). Operational Performance Evaluation of International Major Airports: An Application of Data Envelopment Analysis. Journal of Air Transport Management, 12, 342351.

Lin, C., Ma, Y., \& Su, D. (2009). Corporate Governance and Firm Efficiency: Evidence from China's Publicly Listed Firms. Managerial and Decisions Economics, 30 (3), 193-209.

Lipton, M., \& Lorsch, J. (1992). A Modest Proposal for Improved Corporate Governance. The Business Lawyer, 48, 59-77.

Luhnen, M. (2009). Determinants of Efficiency and Productivity in German Property-Liability Insurance: Evidence from 1995-2006. Geneva Papers on Risk and Insuranc, 34(3), 483-505

Luo, X. (2003). Evaluating the Profitability and Marketability Efficiency of Large Banks: An Application of Data Envelopment Analysis. Journal of Business Research, 56, 627-635.

Maamor, S., \& Ismail, A. (2010). The Ar-Rahnu Efficiency and Its Determinants. Journal of Islamic Economics, Banking and Finance, 6 (1), 105-125.

Macpherson, M. (2001). Performance Measurement in Not-for-profit and Public Sector Organisations. Measuring Business Excellence, 5 (2), 13-17.

Mahamood, S. M. (2006). Waqf in Malaysia : Legal and Administrative Perspective. Waqf in Malaysia: Legal and Administrative Perspective. Kuala Lumpur: University of Malaysia Press.

Majlis Agama Islam Johor. Retrieved on $8^{\text {th }}$ January 2013 from www.maij,gov.my.

Majlis Agama Islam Perak. Retrieved on 15th January, 2013 from www.maiamp.gov.my.

Majlis Agama Islam Selangor. Retrieved on $27^{\text {th }}$ February, 2013 from www.mais.gov.my.

Majlis Agama Islam Pulau Pinang. Retrieved on $5^{\text {th }}$ March, 2013 from mainpp.gov.my

Majlis Agama Islam Kedah. Retrieved on 16 April 2013 from www.maik.gov.my

Majlis Agama Islam Wilayah Persekutuan. Retrieved on $3^{\text {rd }}$ May 2013 from www.maiwp.gov.my.

Miller, S. M., \& Noulas, A. G. (1996). Technical Efficiency of Large Bank Production. Journal of Banking \& Finance, 20, 495-509.

Mohd Salleh, S., \& Muhammad, S. (2008). Waqaf Development In Malaysia : Issues and Challenges. Jurnal Pengurusan JAWHAR, 2 (1), 13-35.

Nanka-Bruce, D. (2011). Corporate Governance Mechanisms and Firm Efficiency. International Journal of Business and Management, 6 (5), 28-40.

Noor, M. A. N. M., \& Ahmad, N. H. B. (2012). The Determinants of Islamic Banks' Efficiency Changes: Empirical Evidence from the World Banking Sectors. Global Business Review, 13 (2), 179-200.

O'Regan, K., \& Oster, S. M. (2005). Does the Structure and Composition of the Board Matter? The Case of Nonprofit Organizations. Journal of Law, Economics, and Organization, 21(1), 205-227.

Rebeiz, K. S., \& Salameh, Z. (2006). Relationship Between Governance Structure and Financial Performance in Construction. Journal of Management in Engineering, 22 (1), 2-26.

Rosman, R., Abd Wahab, N., \& Zainol, Z. (2013). Efficiency of Islamic Banks during the Financial Crisis: An Analysis of Middle Eastern and Asian countries. Pacific-Basin Finance Journal, 28, 7690.

Said, A. (2012). Efficiency in Islamic Banking During a Financial Crisis: An Empirical Analysis of FortySeven Banks. Journal of Applied Finance \& Banking, 3(2), 163-197. 
INTERNATIONAL JOURNAL OF ACADEMIC RESEARCH IN BUSINESS AND SOCIAL SCIENCES

Vol. 10, No. 10, 2020, E-ISSN: 2222-6990 @ 2020 HRMARS

Saleh, N. M., Iskandar, T. M., \& Rahmat, M. M. (2005). Earnings Management and Board Characteristics Evidence from Malaysia. Journal of Management, 24, 77-103.

Samolyk, K. A. (1992). Bank Performance and Regional Economic Growth: Evidence of a Regional Credit Channel. (Working Paper No. 9204). Federal Reserve Bank of Cleveland, Research Department.

Shivdasani, A., \& Yermack, D. (1999). CEO Involvement in the Selection of New Board Members: An Empirical Analysis. Journal of Finance, 54, 1829-1853.

Sufian, F. (2007a). The Efficiency of Islamic Banking Industry: A Non-parametric Analysis with Nondiscretionary Input Variable. Islamic Economic Studies, 14 (1), 53-78.

Sufian, F. (2007b). The Efficiency of Islamic Banking Industry in Malaysia. Humanomics, 23 (3),174 192.

Sulaiman, M., Adnan, M. A., \& Nor, M. M. P. N. (2009). Trust Me! A Case Study of the International Islamic University Malaysia's Waqf Fund. Review of Islamic Economics, 13 (1), 69-88.

Vafeas, N. (1999). Board Meeting Frequency and Firm Performance. Journal of Financial Economics, $53,113-142$.

Witte, K. De, \& Geys, B. (2011). Evaluating Efficient Public Good Provision: Theory and Evidence from a Generalised Conditional Efficiency Model for Public Libraries. Journal of Urban Economics, 69 (3), 319-327.

Xu, Z. (2011). Technical, Pure Technical and Scale Efficiency of China's Banking Industry. 2011 International Conference on Information Management, Innovation Management and Industrial Engineering. Institute of Technology Shenzhen, China.

Yuengert, A. M. (1993). The Measurement of Life Insurance: Estimates of a Mixed Normal-Gamma Error Model. Journal of Banking and Finance 17(2-3), 483-496. 